\title{
Effect of Artificial Short Day Conditions on Growth and Flowering of Chrysanthemum (Chrysanthemum morifolium Ramat.) Genotypes
}

\author{
Ranjit Singh* and Madhu Bala \\ Department of floriculture and Landscaping, Punjab Agricultural University \\ Ludhiana-141004, Punjab, India \\ *Corresponding author
}

\section{Keywords \\ Chrysanthemum (Chrysanthemum morifolium Ramat.) \\ Article Info \\ Accepted: \\ 24 August 2018 \\ Available Online: \\ 10 September 2018}

\section{A B S T R A C T}

In India, it is popular among the farmers as Guldaudhi is a commercial flower which is grown for cut flowers, loose flowers, pot mum as well as bedding plant. Flowering in Chrysanthemum morifolium Ramat. is photperiodically controlled and it is a qualitative short day plant. Under sub-tropical climatic conditions of North India, chrysanthemum produces flowers from October to December. Limited duration of flower production in chrysanthemum is a major bottleneck for the commercialization of this crop in this region. Thus the artificial short days play an important role in altering the flowering of chrysanthemum plants through the manipulations in the daily day length or photoperiod has been successfully used for production of chrysanthemum flowers throughout the year in many countries. Study was conducted to investigate the effect of artificial short day conditions during summer months on growth and flowering of spray type chrysanthemum genotypes. It was found that genotypes Banlgori Local and Yellow Delight are highly suitable for early induction flowering as these are having comparatively high tolerance towards heat delay for year round cultivation programmes using black outs to impose short day conditions.

\section{Introduction}

Florist's chrysanthemum (Chrysanthemum morifolium Ramat.) belongs to the family Asteraceae. This flower crop is popularly known with some other names in different parts of the world such as “Autumn Queen' or 'Queen of the East' (Koley and Sarkar, 2013). The word Chrysanthemum is derived from two Greek words that is 'chrysos' means golden and 'anthos' means flower (Gortzing and Gillow, 1964). In India, it is popular among the farmers as Guldaudhi is a commercial flower which is grown for cut flowers, loose flowers, pot mum as well as bedding plant. Flowering in Chrysanthemum morifolium Ramat.) is photperiodically controlled and it is a qualitative short day plant that requires $14.5 \mathrm{~h}$ photoperiod for flower initiation and $13.5 \mathrm{~h}$ light period for bud development (Runkle and Fisher, 2004). Under sub-tropical climatic conditions of North India, chrysanthemum produces flowers from October to December. Limited duration of flower production in chrysanthemum is a major bottleneck for the commercialization of 
this crop in this region. Thus the artificial short days play an important role in altering the flowering of chrysanthemum plants as reported that the manipulations in the daily day length or photoperiod has been successfully used for production of chrysanthemum flowers throughout the year in many countries (Dutta and Gupta, 2012).

\section{Materials and Methods}

The experiment was conducted at department of floriculture and Landscaping, Punjab Agricultural University during 2015-16.

\section{Experimental layout}

The plants of 10 genotypes of belonging to spray type chrysanthemum, namely Banglori Local, Boris Becker, Reagan White,Kelvin Mandarin, NBRI Sunil, Reagan Emperor, Otome Pink, Jaya, Punjab Shyamli and Yellow Delight, were through the rooting of terminal cuttings during February -March The terminal cuttings measuring $2-3 \mathrm{~cm}$ long were treated with NAA $\left(500 \mathrm{mg} \mathrm{l}^{-1}\right)$ for $30 \mathrm{sec}$ and planted in propagation trays using burnt rice husk as rooting medium. The trays were placed under shading net and sprayed thrice with water daily, to maintain high relative humidity.

After two weeks, when the cuttings had produced sufficient roots, they were removed from the trays along with ball of burnt rice husk to prevent breaking of roots. The rooted cuttings were transplanted in the pots of $20 \mathrm{~cm}$ diameter containing mixture of garden soil and well rottened farm yard manure (2:1) along with diammonium phosphate @ 1 kg per cubic feet. The pots were placed under artificially created short day conditions from $15^{\text {th }}$ June to $15^{\text {th }}$ August. The short days were provided as night extension by using black polythene(100 micron) sheet from civil twilight in the morning to 9.30 am everyday. There after the plants were be shifted to natural day length on $1^{\text {st }}$ September.

The genotypes were subjected to pinching one month after planting. The observations were recorded on plant height, spread, number of branches per plant, leaf area index, number of stomata per unit area, leaf weight ratio, days taken for bud appearance, days to flowering, flower size, anthocyanin and carotenoids content, duration of flowering, number of flowers per plant and vase life

\section{Statistical analysis}

Experiment was laid out with three replications consisting five pots each in completely randomized design. The effect of artificially created short days was noted down on flowering and vegetative parameters at the time of bud emergence. Statistical analysis was performed using SAS software and the means were compared using Duncan Multiple Range Test (DMRT) at 5\% level of significance (Duncan, 1955)

\section{Results and Discussion}

Effect of artificial short days on plant height, spread and number of branches

In Chrysanthemum morifolium genotypes (spray type), the photoperiodic treatments significantly $(p<0.05)$ influenced the plant height, plant spread and number of branches per plant were recorded at time of visible bud appearance (Table 1)

The highest plant height $(85.33 \mathrm{~cm}, 86.00 \mathrm{~cm})$ was observed in genotype Boris Becker which was at par with genotype Punjab Shyamli $(82.33 \mathrm{~cm}, 82.33 \mathrm{~cm})$ in 2015 and 2016, respectively. Whereas, the minimum plant height was observed in genotype Banglori Local $(63.00 \mathrm{~cm}, 65.33 \mathrm{~cm})$ which was at par with genotype Kelvin Mandarin $(67.33$ cm, 
$68.00 \mathrm{~cm})$, Yellow Delight $(65.33 \mathrm{~cm}, 65.33$ $\mathrm{cm})$, Reagan White $(65.00 \mathrm{~cm}, 65.67 \mathrm{~cm})$, Otome Pink $(64.00 \mathrm{~cm}, 65.67 \mathrm{~cm})$ and Reagan Emperor $(64.00 \mathrm{~cm}, 66.33 \mathrm{~cm})$ in 2015 and 2016, respectively. The findings are in accordance with those as have been reported by (Dutta and Gupta, 2012). While classifying the Chyrsanthemum genotypes for year round cultivation using artificial short days.

Effect of artificial short days on leaf area index, number of stomata per unit area and leaf weight ratio

The short day treatments showed nonsignificant $(p<0.05)$ affect on the Leaf area Index and number of stomata per unit area in Chrysanthemum morifolium spray type genotypes (Table 2).

The highest leaf area index (0.321 and 0.317) was observed in genotype Banglori Local in 2015 and 2016, respectively. Whereas, minimum leaf area index (0.183 and 0.207) was observed in genotype Yellow Delight in 2015 and 2016, respectively. In case of number of stomata per unit area the highest number was 57.00 and 57.33 in genotype Otome Pink, whereas, the lowest number was 53.00 and 53.33 in genotype Boris Becker during 2015 and 2016, respectively.

The effect of short day treatments was significantly influenced the leaf weight ratio of all the genotypes. However, the highest leaf weight ratio was observed as 0.293 and 0.287 in genotype Otome Pink, whereas, the minimum leaf weight ratio was observed as 0.144 and 0.145 in genotype Kelvin Mandarin during 2015 and 2016, respectively.

The findings are in accordance with those as have been reported by Kaur (2014) while evaluating the Chyrsanthemum genotypes for morphological and physiological characteristics.
Effect of artificial short days on days taken for bud appearance, days to flowering and flower size

The short day treatments significantly $(p<0.05)$ influenced the days taken for bud appearance, days to flowering and flower size in Chrysanthemum morifolium (spray type) genotypes (Table 3).

The maximum days taken for bud appearance $(156.00,160.67)$ was observed in genotype Reagan Emperor which was at par with genotype Regan white $(154.00,157.67)$, Boris Becker $(155.33,156.00)$ and Kelvin Mandrin $(145.33,152.33)$ in 2015 and 2016, respectively. Whereas, the minimum days taken for bud appearance was observed in genotype Yellow Delight $(108.00,100.67)$ in 2015 and 2016, respectively.

The effect of short day treatments was significantly among all the genotypes for days to flowering. The highest days to flowering (185.33, 186.00) were in genotype Reagan Emperor during 2015 and 2016, respectively.

The values were at par with genotype Boris Becker, Regan white, Kelvin Mandarin and Otome Pinkin 2015 and 2016. Whereas, the minimum days to flowering $(132.67,131.33)$ was observed in genotype Yellow Delight in 2015 and 2016, respectively.

Dutta and Gutpa (2012) have also reported the response of small flowered Chrysanthemum to artificial short days. They have classified the genotypes according to their response to short days. However, the delay in flowering of other genotypes may be attributed due to 'heat delay' as reported by Shibata and Kawata (1997). 'Heat delay' is reported to be severe problem in year around cultivation of Chrysanthemum which is caused by high temperature under blackouts (Furuta and Nelson 1953). 
Table.1 Effect of artificial short-day conditions on plant height, spread and number of branches per plant in spray chrysanthemum

\begin{tabular}{|c|c|c|c|c|c|c|c|}
\hline \multirow[t]{2}{*}{ S. No. } & \multirow[t]{2}{*}{ Genotype } & \multicolumn{2}{|c|}{ Plant height (cm) } & \multicolumn{2}{|c|}{ Plant spread (cm) } & \multicolumn{2}{|c|}{ Number of branches/plant } \\
\hline & & 2015 & 2016 & 2015 & 2016 & 2015 & 2016 \\
\hline 1 & Banglori Local & $63.00^{\mathrm{d}}$ & $65.33^{c}$ & $13.33^{\mathrm{e}}$ & $13.33^{\mathrm{d}}$ & $2.00^{b}$ & $2.00^{b}$ \\
\hline 2 & Boris Becker & $85.33^{\mathrm{a}}$ & $86.00^{\mathrm{a}}$ & $19.33^{\mathrm{ab}}$ & $18.67^{\mathrm{ab}}$ & $3.00^{b}$ & $2.67^{b}$ \\
\hline 3 & Reagan White & $65.00^{\mathrm{d}}$ & $65.67^{c}$ & $14.33^{\mathrm{de}}$ & $13.33^{\mathrm{d}}$ & $3.00^{b}$ & $3.00^{b}$ \\
\hline 4 & Kelvin Mandarin & $67.33^{d}$ & $68.00^{c}$ & $15.00^{\mathrm{de}}$ & $15.00^{\mathrm{cd}}$ & $3.00^{b}$ & $2.67^{b}$ \\
\hline 5 & NBRI Sunil & $73.00^{c}$ & $75.00^{b}$ & $15.00^{\mathrm{de}}$ & $15.33^{\mathrm{bcd}}$ & $2.33^{b}$ & $2.67^{b}$ \\
\hline 6 & Reagan Emperor & $64.00^{d}$ & $66.33^{c}$ & $18.00^{\mathrm{abc}}$ & $17.00^{\mathrm{abc}}$ & $2.00^{b}$ & $2.00^{b}$ \\
\hline 7 & Otome Pink & $64.00^{\mathrm{d}}$ & $65.67^{\mathrm{c}}$ & $20.33^{\mathrm{a}}$ & $20.00^{\mathrm{a}}$ & $2.00^{\mathrm{b}}$ & $2.00^{\mathrm{b}}$ \\
\hline 8 & Jaya & $77.67^{\mathrm{bc}}$ & $78.00^{\mathrm{b}}$ & $16.67^{\mathrm{bcd}}$ & $17.00^{\mathrm{abc}}$ & $4.33^{\mathrm{a}}$ & $4.33^{\mathrm{a}}$ \\
\hline 9 & Punjab Shyamli & $82.33^{\mathrm{ab}}$ & $82.33^{\mathrm{a}}$ & $14.00^{\mathrm{de}}$ & $15.00^{\mathrm{cd}}$ & $5.00^{\mathrm{a}}$ & $5.00^{\mathrm{a}}$ \\
\hline 10 & Yellow Delight & $65.33^{d}$ & $65.33^{c}$ & $15.67^{\text {cde }}$ & $15.67^{\mathrm{bcd}}$ & $2.00^{b}$ & $2.00^{b}$ \\
\hline & Mean & $70.70^{\mathrm{a}}$ & $71.77^{\mathrm{a}}$ & $16.17^{\mathrm{a}}$ & $16.03^{\mathrm{a}}$ & $2.87^{\mathrm{a}}$ & $2.83^{\mathrm{a}}$ \\
\hline
\end{tabular}

Mean values in each column with the same letter are not significantly different at $\mathrm{p}<0.05$ according to DMRT. *Significant at $\mathrm{p}<0.05$

Table.2 Effect of short artificial short-day conditions on plant leaf area index, leaf weight ratio and number of stomata unit area in spray chrysanthemum

\begin{tabular}{|c|c|c|c|c|c|c|c|}
\hline \multirow[t]{2}{*}{ S. No. } & \multirow[t]{2}{*}{ Genotype } & \multicolumn{2}{|c|}{ Leaf area index } & \multicolumn{2}{|c|}{ Leaf weight ratio } & \multicolumn{2}{|c|}{ Number of stomata per unit area } \\
\hline & & 2015 & 2016 & 2015 & 2016 & 2015 & 2016 \\
\hline 1 & Banglori Local & $0.32^{\mathrm{a}}$ & $0.32^{\mathrm{a}}$ & $0.170^{\mathrm{b}}$ & $0.167^{b}$ & $56.67^{\mathrm{a}}$ & $57.33^{\mathrm{a}}$ \\
\hline 2 & Boris Becker & $0.31^{\mathrm{ab}}$ & $0.30^{\mathrm{a}}$ & $0.184^{\mathrm{ab}}$ & $0.183^{\mathrm{ab}}$ & $53.00^{\mathrm{a}}$ & $53.33^{\mathrm{a}}$ \\
\hline 3 & Reagan White & $0.25^{\mathrm{abc}}$ & $0.25^{\mathrm{a}}$ & $0.217^{\mathrm{ab}}$ & $0.213^{\mathrm{ab}}$ & $56.00^{\mathrm{a}}$ & $55.33^{\mathrm{a}}$ \\
\hline 4 & Kelvin Mandarin & $0.25^{\mathrm{abc}}$ & $0.26^{\mathrm{a}}$ & $0.144^{b}$ & $0.145^{b}$ & $54.33^{\mathrm{a}}$ & $55.00^{\mathrm{a}}$ \\
\hline 5 & NBRI Sunil & $0.25^{\mathrm{abc}}$ & $0.26^{\mathrm{a}}$ & $0.159^{b}$ & $0.159^{b}$ & $55.00^{\mathrm{a}}$ & $56.33^{\mathrm{a}}$ \\
\hline 6 & Reagan Emperor & $0.25^{\mathrm{abc}}$ & $0.91^{\mathrm{a}}$ & $0.149^{b}$ & $0.150^{b}$ & $56.67^{\mathrm{a}}$ & $57.00^{\mathrm{a}}$ \\
\hline 7 & Otome Pink & $0.23^{b c}$ & $0.27^{\mathrm{a}}$ & $0.293^{\mathrm{a}}$ & $0.292^{\mathrm{a}}$ & $57.00^{\mathrm{a}}$ & $57.00^{\mathrm{a}}$ \\
\hline 8 & Jaya & $0.32^{\mathrm{a}}$ & $0.30^{\mathrm{a}}$ & $0.192^{\mathrm{ab}}$ & $0.191^{\mathrm{ab}}$ & $56.67^{\mathrm{a}}$ & $57.33^{\mathrm{a}}$ \\
\hline 9 & Punjab Shyamli & $0.31^{\mathrm{ab}}$ & $0.28^{\mathrm{a}}$ & $0.163^{b}$ & $0.162^{b}$ & $55.00^{\mathrm{a}}$ & $56.00^{\mathrm{a}}$ \\
\hline 10 & Yellow Delight & $0.18^{c}$ & $0.21^{\mathrm{a}}$ & $0.218^{\mathrm{ab}}$ & $0.217^{\mathrm{ab}}$ & $55.00^{\mathrm{a}}$ & $55.67^{\mathrm{a}}$ \\
\hline & Mean & $0.27^{\mathrm{a}}$ & $0.34^{\mathrm{a}}$ & $0.218^{\mathrm{a}}$ & $0.188^{b}$ & $55.53^{\mathrm{a}}$ & $56.03^{\mathrm{a}}$ \\
\hline
\end{tabular}

Mean values in each column with the same letter are not significantly different at $\mathrm{p}<0.05$ according to DMRT. *Significant at $\mathrm{p}<0.05$ 
Table.3 Effect of short artificial short-day conditions on days to bud appearance, flowering and flower size in spray chrysanthemum

\begin{tabular}{|c|c|c|c|c|c|c|c|}
\hline \multirow[t]{2}{*}{ S. No. } & \multirow[t]{2}{*}{ Genotype } & \multicolumn{2}{|c|}{ Days taken for bud appearance } & \multicolumn{2}{|c|}{ Days to flowering } & \multicolumn{2}{|c|}{ Flower size (cm) } \\
\hline & & 2015 & 2016 & 2015 & 2016 & 2015 & 2016 \\
\hline 1 & Banglori Local & $117.00^{c}$ & $110.00^{c}$ & $134.67^{\mathrm{d}}$ & $133.67^{\mathrm{d}}$ & $5.33^{\mathrm{cd}}$ & $5.32^{\mathrm{cd}}$ \\
\hline 2 & Boris Becker & $155.33^{\mathrm{a}}$ & $156.00^{\mathrm{a}}$ & $184.33^{\mathrm{a}}$ & $185.33^{\mathrm{a}}$ & $6.33^{\mathrm{abc}}$ & $6.30 \mathrm{a}^{\mathrm{bc}}$ \\
\hline 3 & Reagan White & $154.00^{\mathrm{a}}$ & $157.67^{\mathrm{a}}$ & $184.00^{\mathrm{a}}$ & $183.00^{\mathrm{a}}$ & $7.00^{\mathrm{a}}$ & $7.05 \mathrm{a}$ \\
\hline 4 & Kelvin Mandarin & $145.33^{\mathrm{a}}$ & $152.33^{\mathrm{a}}$ & $174.67^{\mathrm{a}}$ & $181.67^{\mathrm{a}}$ & $3.67^{\mathrm{e}}$ & $3.65^{\mathrm{e}}$ \\
\hline 5 & NBRI Sunil & $141.33^{\mathrm{b}}$ & $142.33^{b}$ & $162.33^{b c}$ & $163.33^{b c}$ & $4.00^{\mathrm{e}}$ & $4.02^{\mathrm{e}}$ \\
\hline 6 & Reagan Emperor & $156.00^{\mathrm{a}}$ & $160.67^{\mathrm{a}}$ & $185.33^{\mathrm{a}}$ & $186.00^{\mathrm{a}}$ & $6.67^{\mathrm{ab}}$ & $6.67 \mathrm{a}^{\mathrm{b}}$ \\
\hline 7 & Otome Pink & $143.33^{b}$ & $144.67^{b}$ & $177.33^{\mathrm{a}}$ & $175.33^{\mathrm{a}}$ & $4.67^{\mathrm{de}}$ & $4.67^{\mathrm{de}}$ \\
\hline 8 & Jaya & $131.00^{\mathrm{bc}}$ & $132.00^{\mathrm{bc}}$ & $156.67^{\mathrm{c}}$ & $155.67^{\mathrm{c}}$ & $7.00^{\mathrm{a}}$ & $7.12 \mathrm{a}$ \\
\hline 9 & Punjab Shyamli & $122.33^{\mathrm{c}}$ & $123.67^{c}$ & $155.67^{c}$ & $154.00^{c}$ & $7.13^{a}$ & $7.25 \mathrm{a}$ \\
\hline 10 & Yellow Delight & $108.00^{d}$ & $107.67^{\mathrm{d}}$ & $132.67^{\mathrm{d}}$ & $131.33^{d}$ & $5.67^{\text {bcd }}$ & $5.58^{\text {bcd }}$ \\
\hline & Mean & $137.30^{\mathrm{a}}$ & $138.70^{\mathrm{a}}$ & $164.78^{\mathrm{a}}$ & $164.93^{\mathrm{a}}$ & $5.75^{\mathrm{a}}$ & $5.76^{\mathrm{a}}$ \\
\hline
\end{tabular}

Mean values in each column with the same letter are not significantly different at $\mathrm{p}<0.05$ according to DMRT. *Significant at $\mathrm{p}<0.05$

Table.4 Effect of artificial short-day conditions on number anthocyanin and carotenoids in spray chrysanthemum

\begin{tabular}{|c|c|c|c|c|c|}
\hline \multirow[t]{2}{*}{ Sr. No. } & \multirow[t]{2}{*}{ Genotype } & \multicolumn{2}{|c|}{ Anthocyanin content (mg/g) } & \multicolumn{2}{|c|}{ Carotenoids content (mg/g) } \\
\hline & & 2015 & 2016 & 2015 & 2016 \\
\hline 1 & Banglori Local & $\mathrm{ND}^{\mathrm{b}}$ & $\mathrm{ND}^{\mathrm{b}}$ & $6.00^{f}$ & $5.67^{\mathrm{f}}$ \\
\hline 3 & Reagan White & $\mathrm{ND}^{\mathrm{b}}$ & $\mathrm{ND}^{\mathrm{b}}$ & $23.00^{c}$ & $22.67 c$ \\
\hline 4 & Kelvin Mandarin & $1.00^{\mathrm{b}}$ & $1.31^{b}$ & $5.67^{\mathrm{f}}$ & $5.67^{\mathrm{f}}$ \\
\hline 5 & NBRI Sunil & $\mathrm{ND}^{\mathrm{b}}$ & $\mathrm{ND}^{\mathrm{b}}$ & $6.67^{f}$ & $7.00^{f}$ \\
\hline 7 & Otome Pink & $0.33^{\mathrm{b}}$ & $0.30^{\mathrm{b}}$ & $44.33^{\mathrm{a}}$ & $43.67^{\mathrm{a}}$ \\
\hline 8 & Jaya & $42.00^{\mathrm{a}}$ & $41.67^{\mathrm{a}}$ & $3.33 \mathrm{~g}$ & $3.00^{\mathrm{g}}$ \\
\hline 9 & Punjab Shyamli & $\mathrm{ND}^{\mathrm{b}}$ & $\mathrm{ND}^{\mathrm{b}}$ & $17.67^{\mathrm{d}}$ & $17.00^{\mathrm{d}}$ \\
\hline 10 & Yellow Delight & $\mathrm{ND}^{\mathrm{b}}$ & $\mathrm{ND}^{\mathrm{b}}$ & $10.33^{\mathrm{e}}$ & $10.00^{\mathrm{e}}$ \\
\hline & Mean & $4.96^{\mathrm{a}}$ & $5.39^{\mathrm{a}}$ & $19.33^{\mathrm{a}}$ & $18.97^{\mathrm{a}}$ \\
\hline
\end{tabular}

Mean values in each column with the same letter are not significantly different at $p<0.05$ according to DMRT. *Significant at $p<0.05$ ND - Not detected 
Table.5 Effect of short artificial short-day conditions on duration of flowering, number of flowers per plant and vase life in spray chrysanthemum

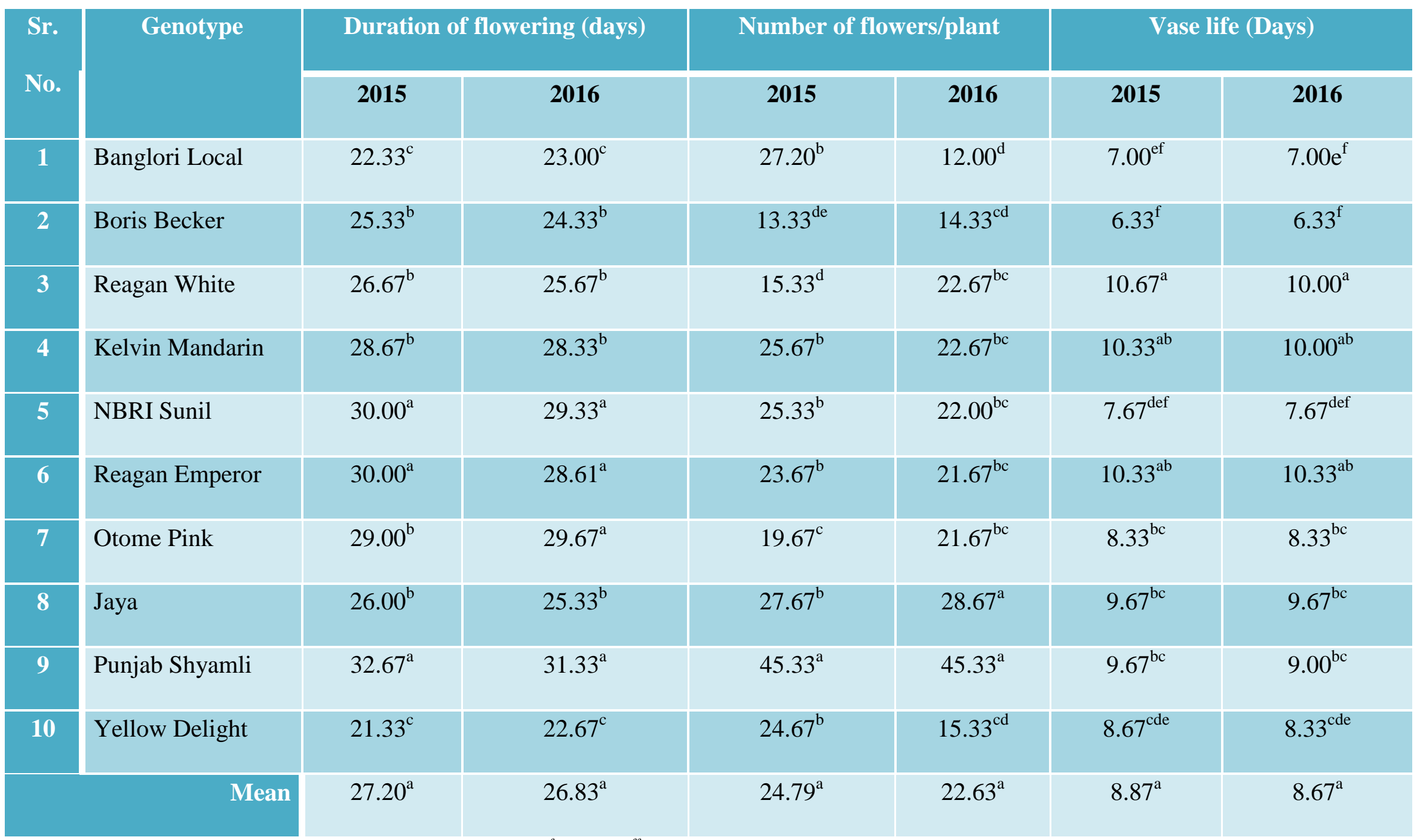

Mean values in each column with the same letter are not signi ${ }^{\mathrm{f}}$ icantly $\mathrm{di}^{\mathrm{ff}}$ erent at $\mathrm{p}<0.05$ according to DMRT. ${ }^{*}$ Significant at $\mathrm{p}<0.05$ 
Shibata and Kawata (1997) have mentioned heat tolerance in some genotypes of Chrysanthemum, so while creating artificial short days using black polythene (100 micron) has lead to increase in termapture inside the polythene upto $40^{\circ} \mathrm{C}$. Based on the observations it was found that genotypes Banglori Local and Yellow Delight were tolerant to 'heat delay' as compared to other genotypes under study.

The short day treatments significantly affect the flower size of all genotypes. The highest value $(7.13 \mathrm{~cm}, 7.25 \mathrm{~cm})$ was in genotype Punjab Shyamli which was at par with genotype Jaya $(7.00 \mathrm{~cm}, 7.12 \mathrm{~cm})$ and Regan White $(7.00 \mathrm{~cm}, 7.05 \mathrm{~cm})$ during 2015 and 2016. The minimum flower size $(3.67 \mathrm{~cm}$, $3.65 \mathrm{~cm}$ ) was found in genotype Kelvin Mandarin which was at par with NBRI Sunil $(4.00 \mathrm{~cm}, 4.02 \mathrm{~cm})$ during 2015 and 2016. The findings are in accordance with those as reported by Gupta and Dutta (2012). They have also reported variation in flower size in response to artificial short days.

\section{Effect of artificial short days on anthocyanin and carotenoids content}

The short day treatment significantly $(\mathrm{p}<0.05)$ influenced the anthocyanin content, carotenoids content in Chrysanthemum morifolium (spray type) genotypes (Table 4).

The maximum anthocyanin content (42.00 $\mathrm{mg} / \mathrm{g}, 41.67 \mathrm{mg} / \mathrm{g}$ ) was observed in genotype Jayain 2015 and 2016, respectively. Whereas, the minimum anthocyanin content was in genotype during 2015,

The highest carotenoids content $(46.33 \mathrm{mg} / \mathrm{g}$, $45.67 \mathrm{mg} / \mathrm{g}$ ) was in genotype Boris Becker in 2015 and 2016, respectively. Whereas, minimum carotenoids content $(3.33 \mathrm{mg} / \mathrm{g}$, $3.00 \mathrm{mg} / \mathrm{g}$ ) was observed in genotype Jayaduring2015and 2016, respectively. The variations in anthocyanin and carotenoids contents have also been documented by Shisa et al., (2017) and Park et al., (2015).

\section{Effect of artificial short days on duration of flowering, number of flowers per plant and vase life}

The effect of artificial short day treatments significantly $(\mathrm{p}<0.05)$ influenced the duration of flowering, number of flowers per plant and vase life in Chrysanthemum morifolium (spray type) genotypes (Table 5).

The maximum duration of flowering (32.67, 31.33) was observed in genotype Punjab Shyamli in 2015 and 2016, respectively. The value was at par with genotypes NBRI Sunil, Reagan Emperor and Otome Pink, whereas, the minimum duration of flowering was 21.33 in genotype Banglori Local during 2015, however, the value was 16.67 in genotype Yellow Delight during 2016. However, Banglori Local and Yellow Delight were at par during during two years.

The highest number of flowers per plant was 45.33 in genotype Pujab Shyamli in 2015 and 2016, whereas, minimum number of flowers per plant (13.33) was observed in genotype Boris Becker in 2015 and 12.00 in genotype Banglori Local during 2016.Chrysanthemum genotypes exhibit considerable variable in flower vase life and number of flowers per plant which are genetically determined characteristics (Larson 1992, Dutta 2006, Dutta and Gupta 2012).

\section{References}

Dutta, S. K. 2006. Advances in Ornamental Horticulture (S K Bhattacharjee ed). Pointer Publishers, Jaipur.

Dutta, S. K. and Gupta, V. N. 2012. Year round cultivation of garden chrysanthemum (Chrysanthemum 
morifolium Ramat) through photoperiodic response. Sci \& Cult 78: 71-77.

Furuta, T. and Nelson, K. S. 1953. The effects of high night termapture on the development of chrysanthemum flower buds. Proc Am Soc Hort Sci 61: 548-50.

Gortzing, C. and Gillow, I. 1964. Chrysanthemum: a manual of the culture. The New York State, Extension Bulletin, pp: 9-17.

Kaur, P.2014.Regulation of flower production and post-harvest keeping quality in chrysanthemum (Chrysanthemum morifolium Ramat). Ph.D. Dissertation. Punjab Agricultural University, Ludhiana, India.

Larson, R. A. 1992.Introduction to Flower culture. $2^{\text {nd }}$ Edn. Academic Press Inc. Sand Diego, California.

Park, C. H., Chae, S. C., Park, S. Y., Kim, J. K., Kim, Y. J., Chung, S. O., Arasu, M. V., Al-Dhabi, N. A. and Park, S. U.
2015. Anthocyanin and carotenoid contents in different cultivars of chrysanthemum (Dendranthema grandiflorum Ramat.) flower. Molecules 20: 11090-11102.

Runkle, E. and Fisher, P. 2004. Photoperiod and flowering. In: Fisher $\mathrm{P} R$ and Runkle E (eds). Lighting up Profits: Understanding Greenhouse Lighting. Pp. 25-32. Meister Media Worldwide, Willoughby, Ohio.

Shibrata, M. and Kawata, J. 1997. The introduction of heat tolerance for flowering from Japanese summer flowering chrysanthemum into year around chrysanthemums. Act Hort 197: $77-82$

Shisa, U. P., Namita, Singh, K.P., and Panwar, S. 2017. Cluster analysis of chrysanthemum (Chrysanthemum $\times$ morifolium Ramat.) genotypeson the basis of anthocyanin and carotenoid pigments. J Orn Hort20:46-53.

\section{How to cite this article:}

Ranjit Singh and Madhu Bala. 2018. Effect of Artificial Short Day Conditions on Growth and Flowering of Chrysanthemum (Chrysanthemum morifolium Ramat.) Genotypes. Int.J.Curr.Microbiol.App.Sci. 7(09): 3770-3777. doi: https://doi.org/10.20546/ijcmas.2018.709.466 